\title{
Impact of E Learning on Students Performance and Expenditures Borne by Students and Virtual Degree Awarding Institutes in Pakistan
}

\author{
Naeem Akhtar, SZABIST Karachi \\ Nazia Aslam, Turbat University \\ Syed Qaiser Hussain, SZABIST Karachi
}

\begin{abstract}
This study has been conducted to examine the impact of distance education through the utilization of e-learning platforms in enhancing the academic performance of the students. Moreover, among other advantages, the research has also assessed the effect of distance education in terms of its benefits that it provides in the form of cost-savings for both students who attain education from remote areas, as well as for educational institutes in providing education without the need to establish more facilities or hire more teachers to reach and teach these students effectively. To conduct this study, quantitative research methodology was utilized and the method of survey was used to collect the primary data related to the key variables of this research. 100 students from Karachi were selected for this research by using the convenience sampling technique and a questionnaire was distributed to them to gather the relevant data. The statistical techniques related to correlation, regression and Cronbach Alpha analyses were utilized under this research to draw appropriate inferences about its hypotheses. The findings of the research revealed that the provision of distance education through the technology/platforms of e-learning was playing a significant role in both enhancing the performance of the students and in reducing the costs for the students and educational institutes (like universities) to attain and provide education from the remote areas, respectively
\end{abstract}

Keywords: learning, students, performance.

Received: 07.12.2020 $\quad$ Accepted: 16.01.2021 $\quad$ Published: 09.02.2021

\section{INTRODUCTION}

E-Learning can be described as a novel technique that is frequently getting used under the industry of education and involve the utilization of various technologies to help students in completing their courses outside of their traditional/conventional classrooms (Farid et al., 2015). The technologies that are utilized under e-learning are dependent upon the use of the internet, as it can be used effectively to provide education to the students even in remote areas that may be located miles away from the physical university or school (Nawaz \&Kundi, 2010).

E-learning can comprise various activities which can include videos, online games, as well as utilization of virtual blackboards and even applications like Skype. It is considered as one of the most effective approaches to enhance the learning experience of the students as it also helps them to give appropriate attention to their studies under their busy schedule (Shah et al., 2013). On the other hand, distance education is defined as the method of providing education through electronic media or the internet to those students who might not be physically present within the school, college or university.

In Pakistan, the provision of this type of education in various cities that are offered by the universities is usually made possible through the utilization of the technologies associated with e-learning (Qureshi et al., 2012).This research will analyze how virtual universities are utilizing the technology of elearning to provide distance education to the students and what benefits both the management of these universities and students have been able to gain from the use of e-learning.

It has been observed that students who live in remote or distant areas, often face difficulties to gain access to high-quality education due to the lack of proper educational facilities and institutes. Moreover, it is also observed that those students, who have a busy work schedule or who are married are not able to give proper attention to their studies (Iqbal \& Ahmad, 2010). Similarly, insufficient income levels of the students also make it difficult for them to take admission within the top universities and even if they get successful in 
attaining admission under such universities, they are compelled to face high traveling costs in order to visit and attend their classes in these universities.

As a result of these problems, the students often suffer in their studies by not attaining quality education as they fail to get admission in their preferred universities due to their limited financial capital or their inability to travel from remote or distant areas in order to visit the university's premises/campuses. Moreover, those students who have busy schedules or who face difficulty in managing their time appropriately (due to the lack of time-flexibility associated with traditional teaching methods) have been observed to get poor grades, which caused them to flunk in their courses. In addition to this, providing quality education for many educational institutes in Pakistan is not an easy task, since it requires a significant amount of capital to build appropriate infrastructure, campuses and facilities for the students so that they are able to visit these institutes and gain education appropriately (Nawaz \&Kundi, 2010).

Moreover, in some higher education institutes within Karachi, the admission/enrolment of the students is increasing substantially, which is making it difficult for these institutes to provide more capacity to the students under their current and limited infrastructure, which again is increasing the challenges for these universities to provide education to the students effectively (Kanwal \& Rehman, 2014). However, this problem can be effectively solved by the platforms of e-learning, since it is not only considered as a costeffective method to provide distance education, but it can also allow the students to gain access of the quality education which they seek from their homes by using electronic devices like computers or mobile phones (Qureshi, Raza \& Whitty, 2014).

Furthermore, it also provides flexibility to the students in managing their studies within their busy schedules in an appropriate way, which again helps them to organize their learning process in the most suitable ways according to their own preferences (Sajid, 2013). Similarly, providing distance education through using the platform of e-Learning also helps educational institutes to save their costs associated with establishing new branches/campuses and hiring additional teachers to provide education to the students in remote areas. This is because by utilizing the technology of e-learning (such as the provision of video lectures), universities are able to utilize their existing resources, teachers and facilities to provide highquality education without facing the need to establish new branches or campuses. Therefore, in light of the above analysis, the following objectives have been proposed for this research in the below-provided section. The theory of situated learning which was proposed by Lave has contended that learning as it usually occurs is a function of the culture, context, and activity under which it is provided (i.e., the surrounding situation). This theory contradicts with most type of learning activities in the classrooms that typically involve knowledge which is out of context or is provided in abstract form (Korthagen, 2010). The application of this theory under the context of e-learning and distance education emphasize that:

- Teachers should offer various perspectives to assess different solutions and problems of the students.

- Teachers should facilitate students in presenting their products (i.e., class activities, homework) under the virtual environment.

- Teachers should encourage students to question their provided answers by asking how and why they have arrived on a particular answer to a given problem.

- Teachers should motivate students to reflect on their learning processes (Dawley\&Dede, 2014).

Naresh, and Pricilda (2016) have stated in their report that within today's competitive environment of the world, under which people are compelled to update or enhance their knowledge every day in response to global exposure, learning has been considered as a lifelong process. Naresh et al. (2016) argued that within the sector of education, it is important to sustain competitiveness by inducing technology within the process of learning. By utilizing various tools associated with technology, the processes of teaching and learning can be conducted easily by using any type of electronic media which can include video, audio, satellites, TV, and so forth around the world in any country. Moreover, Akhtar and Tuba (2015) recommended effectiveness of modern technology tools including learning softwares to enhance students' skills.

Chapman and Henderson (2010) mentioned that in these situations, a key role has been played by elearning to disseminate knowledge, where approximately 90 percent of educational institutes like colleges that are located in countries such as the United States are offering different courses of e-learning and emerging economies like Pakistan and India, have also been observed to possess significant potential to attain growth within their higher education sectors through the mode of e-learning. However, there is a significant gap within the CAGR (i.e., Compound Annual Growth Rate) of both faculty, as well as student enrolment in these countries. Moreover, in some countries, such as India, there is also a substantial gap between the enrolments of both postgraduate and undergraduate students. 
For instance, according to the census of Indian population, approximately 60 percent people were observed to belong from middle age group who were also working as full-time employees and wanted to update or enrich their learning processes and knowledge without going to any premises or physical classrooms of the educational institutes in order to attend the lectures provided by their teachers. The research of Naresh et al. (2016) also implied that the most significant challenge which is faced by the technology of e-learning in today's environment is based on monitoring or inspecting the validity of the individuals with respect to the enrolled courses and to see whether the individual students have undergone through the assessment procedures in a right or legal manner.

According to Truong (2016), e-learning platforms to provide various training programs are designed to cover different hierarchical degrees within the universities, which are easily configured to meet the specific needs of the students, their positions and the requirements demanded by the environment of their studies. Moreover, unlike traditional education, Jung, Wong, and Belawati (2013) stated that e-learning platforms that are considered as the new model of education will help to make significant monetary savings for the universities in their educational material because everything is supported in a database. There will also be fewer expenses in transportation since the students are not required to leave the comfort of their homes or offices. The synchronous or asynchronous support of the teacher, tutor or expert in e-learning platforms can help to provide the advantage of teaching to several people at the same time and through the use of elearning, the need to hire additional teaching staff will be diminished (Kundi \& Nawaz, 2014)

Education, for centuries, has been observed to consistently rely upon traditional methods of teaching and learning under a typical classroom environment. However, the learning process which has been improved by the use of novel technology is increasing the potential to revolutionize the ways of attaining education for a large number of students by making it more cost-effective and easy to access for them (Latchem \& Jung, 2012). In the contemporary society, the technology providing social networking sites have also been proved fruitful in enhancing the learning experiences of the students which can be used as one of the e-learning devices (Akhtar\& Tuba, 2015). These technologies also include the use of e-learning which is enabling people to attain education anywhere and at any time (i.e., distance education) from a particular location that is most convenient for them. The merits of this technology also include the ability to reach larger markets, reductions in costs, improved learning of the students which helps to offer personalized experience or instructions to them and provision of more flexibility (Miller et al., 2013).

However, in order to utilize the technology of e-learning to its full potential, it is important for various suppliers who provide systems, services, and contents to facilitate the learning process in this technology to work together appropriately. Nevertheless, within information technology, training based on the use of different software and modern education methods, the continual advances are increasingly providing a flexible, as well as cost-effective alternative to provide education to the students in comparison to those traditional learning methods that require face-to-face interaction and physical presence of both the teachers and students at the same place (Al-Qahtani\& Higgins, 2013).

Likewise, King and Boyatt (2015) also supported e-learning by stating that one of the great benefits of online training based on e-learning, and for which more and more people around the world are betting on it is that there are no geographical barriers. The training that is offered to a student is not limited only to the area where he/she resides, but it also contains courses and programs of the institutions from around the world at his/her disposal on a single click. Mayer (2017) also acknowledged in their research that e-Learning courses offer a wide selection of tools, resources, and materials that help the student throughout the entire training process, such as videos, audios or extra materials, and helps them to maintain direct contact with the tutor.

Furthermore, Aparicio, Bacao, and Oliveira (2016) mentioned in their report that currently, the world is constantly evolving. Therefore, the course material of a certain subject can become obsolete in a matter of months. However, in an e-Learning course, the team of teachers offers exactly those contents in the course or learning materials that they consider most appropriate. In addition, these learning materials also have the possibility of being updated at any time. In this way, the student has the assurance of acquiring upto-date knowledge.

Even though e-learning might be perceived by the people as a tool that can be used by anyone, in reality, however, it is not usually the case. This is because not everyone possesses stable access to the internet, which also includes powerful computers that are required to support the online streaming of the video, which a student might be trying to access while gaining education on the e-learning platforms (Assareh\&Bidokht, 2011). Whereas some individuals might have all the mandatory technologies that are 
needed for e-learning, but they might face difficulty regarding how to use them appropriately due to their lack of knowledge. For instance, those students who are older face difficulty in mastering the use of novel tech gigs. Nevertheless, this issue can be resolved through the provision of proper tutorials or training related to using e-learning platforms effectively (Njenga\&Fourie, 2010).

The ability to organize the process of learning according to one's own preference and to learn at one's own comfortable pace can be a catastrophe for some students. Even though several people are better at organizing themselves, but there are a majority of those individuals who face difficulty in managing their studies appropriate unless they are provided with clear deadlines related to writing a term paper (Ahmed, Hussain, \&Farid, 2018). This also includes the need for reporting their progress or performance to their teachers. These individuals are also the ones who feel more motivated around people, which in turn, helps to facilitate their learning process. Thus, the use of e-learning technologies will not be appropriate to provide education to these people (Kimiloglu, Ozturan, \&Kutlu, 2017).

Similarly, for several students, the campuses or premises of their educational institute is not only the place from where they attain education. This is because it is also the place in which they are able to socialize with others, learn new things from their teachers, participate in extra-curricular activities or make new friends (Chang, 2016). The platforms of e-learning cannot provide such types of provisions in most cases to the students. Indeed the students are able to chat with others or ask questions from their teachers online, but they will not be able to experience the same level of personal connection that this found under a traditional classroom or at premises of the educational institute. This, as a result, make several students feel isolated as they think that they have been deprived of the needed personal support (Cook \&Triola, 2014).

In addition to this, within the progress of any student, feedback is considered as one of the most important drivers. This is because improvements within the learning process are only made by the students effectively when they are able to understand their weak points or flaws. Thus, even though online instructors or teachers are able to give feedback to the students on theplatforms associated with e-learning, they still face difficulties in providing appropriate time to each student in order to work on their weak point in more detail and this, in turn, makes several students fall behind from their colleagues in the same classroom (Cakmak\&Yilmaz, 2014). Having such an inability to provide appropriate time to develop students and the resulting gaps that are generated within their knowledge due to lack of appropriate attention from the teacher can make it difficult for some students to complete their courses successfully on the platforms of elearning (Macleod \& Kefallonitis, 2017).

Distance education is described by Gunawardena and McIsaac (2013) as an independent educational method or system, which does not require any face-to-face communication between the teacher and student, and it is mediated by various technologies. Anderson and Dron (2011) have defined it as a planned teaching and learning method, under which the teaching process takes place in a different place than learning, and it requires communication through technologies that might be related to the utilization of e-learning.

Distance education has changed the traditional schemes in the teaching-learning process, both for the teachers and for the students, as there is no direct real-time relationship for the teacher to deliver the lectures and the student's learning process becomes more flexible because there is no physical concurrence in terms of place and time during the teaching process. Moreover, it also requires greater independence and self-regulation by the student. Distance education adopts various peculiarities depending on the intermediation, time and channel that used to deliver the lecture or learning materials (Moore \&Kearsley, 2011).

The concept of distance or virtual education has changed with the rise of digital telecommunications and information and communication technologies and this has allowed better and faster ways to disseminate knowledge (Boling et al., 2012). The networks of the telecommunications systems allow people and groups to have fast and reliable connections, which has allowed a greater interrelation of information between them. Peters (2013) has argued that the integration of the fields of computer science, audiovisual media and telecommunications has also created a positive impact on the quality of distance education that is provided to the students globally.

According to Rovai and Downey (2010), distance education helps to provide students a significant comparative advantage to manage their time appropriately. This is important especially for those students that are also employed or work in their jobs while conducting their studies. For these students, their jobs are also a matter of priority upon which they place the same level of importance just like they do for their education. Thus, distance education assists these students by providing them the benefit of flexible studying 
hours that, in turn, also aids them to perform their jobs without facing any type of problem or hindrance, which further motivates them to contribute to the development of their nations.

Likewise, Chetwynd and Dobbyn (2011) also supported distance learning by stating that it not only aids to enhance the abilities or skills of the students but it also helps them significantly to earn more in their future jobs by enhancing their worth in the eyes of the potential employers. Furthermore, in several developing countries, women face problems in getting high-quality education because of the narrow mindset of their families and this problem is also prevalent in Pakistan. As a result of this mindset, many women are compelled to stop their studies as they are made to marry without even completing their education appropriately. Distance education or learning can provide a golden opportunity for such women to start their studies again and accomplish their dreams or ambitions, which might also help the countries like Pakistan to enhance their literacy and employment rate significantly (Kibelloh\&Bao, 2014).

Ozcan and Genc (2016)also argued that students are assisted by distance education when they want to enroll themselves in different courses that might not be accessible or available within the educational institutes located in their immediate geographical locality. For instance, modes of distance education like elearning can help students of Karachi to easily apply within the educational institutes of Islamabad to attain education within their chosen or preferred courses effectively. This can also help a student to complete his/her studies appropriately from his/her home in Karachi without going anywhere and, in turn, can aid to develop multi-talented professionals in the country. Under the study of Gauvreau et al. (2016) it was also mentioned that the provision of distance education is also considered as economical in nature. This is because it does not compel students, as well as their parents to spend a huge sum of money to attain education. Moreover, students are also able to save their money from this mode of education, which helps them to invest their extra money or funds in other productive ways that further benefit them significantly.

\section{Objectives of the study}

- To analyze the benefits that the students in Karachi have been able to attain from the distance education provided by virtual universities through the utilization of e-learning technologies.

- To analyze the benefits for the management of virtual universities that they have been able to attain by using e-learning technologies to provide distance education.

\section{Research Questions}

- What benefits students in Karachi have been able to attain from distance education that is provided by virtual universities through the utilization of e-learning technologies?

- What benefits the management of such virtual universities have been able to attain by using e-learning technologies to provide distance education to their students?

\section{METHODOLOGY}

The design of this research was based on primary quantitative methodology using convenient and purposive sampling methods. The quantitative technique or analysis of this study focused on producing measurable data for which a survey was conducted during the research process to gain more information regarding the variables and their relationship.

\section{Hypotheses}

H1. There is an impact of e-learning in providing distance education with the expenditures borne by students to attain education.

H2. There is an impact of e-learning in providing distance education with the performance/grades of the students.

H3.There is an impact of e-learning in providing distance education with the expenditures borne by virtual universities to provide education. 


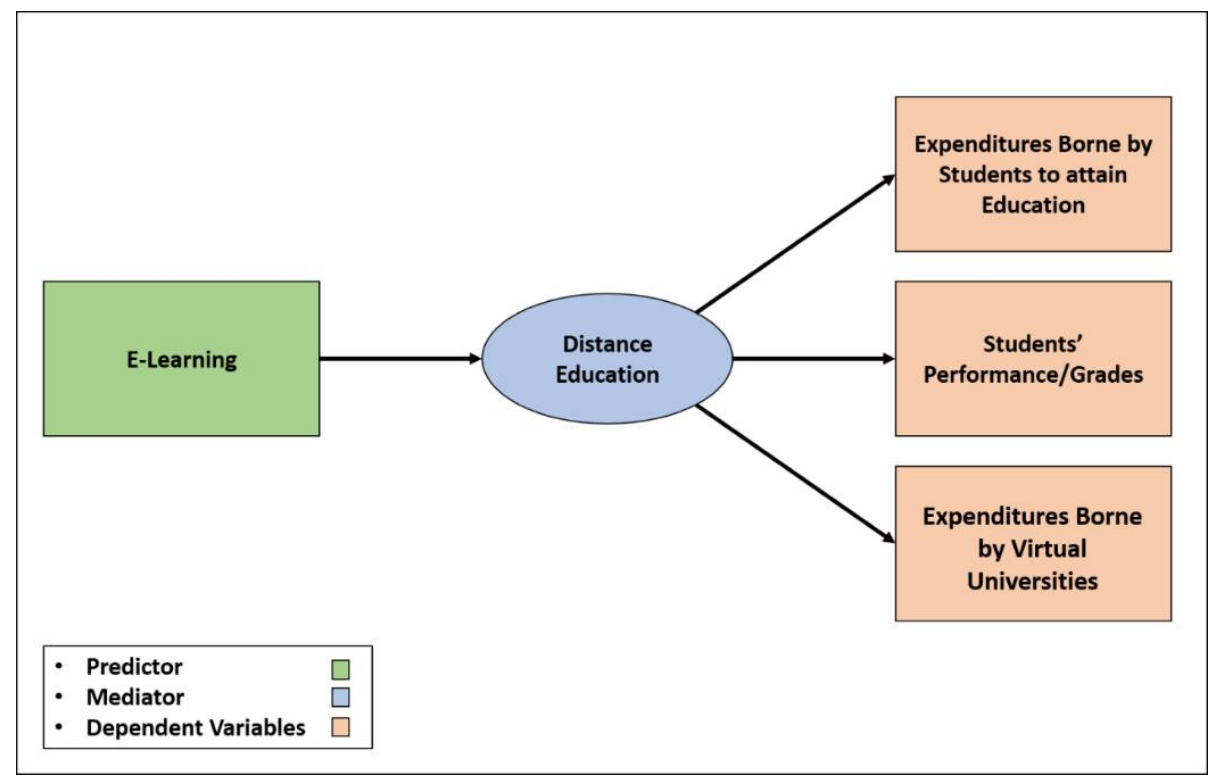

Figure 1. Model Framework

A total of 12 Likert Scale questions was Used to seek the responses from the students (i.e., three questions for each variable). Besides these 12 questions, three demographic questions were also asked under which respondents were required to provide the details of their age, marital status, and income levels (Croasmun \& Ostrom, 2011). In addition to this, four different existing research reports/studies were used in order to take the idea for developing the content of the questionnaire that has been used in the survey of this research.

\section{Demographics}

Upon analyzing the demographic data of the respondents, it is evident that most of the students who were selected for the survey were from the age group of 26 to 35 years (i.e., 23 percent). Similarly, the majority of the students under the sample were single (i.e., 59 percent) and most of them were earning below PKR 20,000 (i.e., 26 percent). The below-provided tables are summarizing the demographic data of the students related to their age group, marital status, and level of income.

Table 1. Age Group of the Respondents

Age

\begin{tabular}{|c|c|c|c|c|c|}
\hline & & Frequency & Percent & Valid Percent & $\begin{array}{l}\text { Cumulative } \\
\text { Percent }\end{array}$ \\
\hline \multirow[t]{6}{*}{ Valid } & Below 18 & 20 & 20.0 & 20.0 & 20.0 \\
\hline & 19 - 25 years & 21 & 21.0 & 21.0 & 41.0 \\
\hline & 26 - 35 years & 23 & 23.0 & 23.0 & 64.0 \\
\hline & $36-45$ years & 14 & 14.0 & 14.0 & 78.0 \\
\hline & 45 years or above & 22 & 22.0 & 22.0 & 100.0 \\
\hline & Total & 100 & 100.0 & 100.0 & \\
\hline
\end{tabular}


Table 2. Marital Status of the Respondents

\section{Marital Status}

\begin{tabular}{|c|c|c|c|c|c|}
\hline & & Frequency & Percent & Valid Percent & $\begin{array}{l}\text { Cumulative } \\
\text { Percent }\end{array}$ \\
\hline \multirow[t]{4}{*}{ Valid } & Single & 59 & 59.0 & 59.0 & 59.0 \\
\hline & Married with Children & 16 & 16.0 & 16.0 & 75.0 \\
\hline & $\begin{array}{l}\text { Married } \quad \text { Without } \\
\text { Children }\end{array}$ & 25 & 25.0 & 25.0 & 100.0 \\
\hline & Total & 100 & 100.0 & 100.0 & \\
\hline
\end{tabular}

Table 3. Income Level of the Respondents

Income Level

\begin{tabular}{|c|c|c|c|c|c|}
\hline & & Frequency & Percent & Valid Percent & $\begin{array}{l}\text { Cumulative } \\
\text { Percent }\end{array}$ \\
\hline \multirow[t]{6}{*}{ Valid } & Below PKR 20,000 & 26 & 26.0 & 26.0 & 26.0 \\
\hline & PKR 21,000 - 30,000 & 21 & 21.0 & 21.0 & 47.0 \\
\hline & PKR 31,000 to 40,000 & 17 & 17.0 & 17.0 & 64.0 \\
\hline & PKR 41,000 to 50,000 & 16 & 16.0 & 16.0 & 80.0 \\
\hline & PKR 51,000 or above & 20 & 20.0 & 20.0 & 100.0 \\
\hline & Total & 100 & 100.0 & 100.0 & \\
\hline
\end{tabular}

Table 4. Reliability Scale

Reliability Statistics

\begin{tabular}{|l|l|}
\hline $\begin{array}{l}\text { Cronbach's } \\
\text { Alpha }\end{array}$ & N of Items \\
\hline .809 & 15 \\
\hline
\end{tabular}

\section{Interpretations}

In table 4, it can be observed that the value of Cronbach's Alpha is around 80.9 percent. This implies that the composite scores on the number of items (i.e., 15 questions) are internally consistent or significantly reliable. The reason why the above value has been considered as reliable is that it is around 80 percent and as per the general rule of thumb, the value of Cronbach's Alpha under (or closer to) this range is usually stated as acceptable or highly reliable(Tavakol \& Dennick, 2011).

\section{E-Learning and Cost Borne by Students}

Table 5. Regression Analysis for Hypothesis 1

Model Summary

\begin{tabular}{|l|l|l|l|l|}
\hline Model & $\mathrm{R}$ & R Square & $\begin{array}{l}\text { Adjusted } \\
\text { Square }\end{array}$ & $\begin{array}{l}\text { Std. Error of } \\
\text { the Estimate }\end{array}$ \\
\hline 1 & $.568^{\mathrm{a}}$ & .322 & .315 & .39256 \\
\hline
\end{tabular}

a. Predictors: (Constant), Provision of Distance Education through

E-Learning

ANOVAa

\begin{tabular}{|ll|l|l|l|l|l|}
\hline Model & & Sum of Squares & df & Mean Square & F & Sig. \\
\hline 1 & Regression & 7.182 & 1 & 7.182 & 46.607 & $.000^{\mathrm{b}}$ \\
& Residual & 15.102 & 98 & .154 & & \\
& Total & 22.284 & 99 & & & \\
\hline
\end{tabular}

a. Dependent Variable: Cost Savings made by Students 
b. Predictors: (Constant), Provision of Distance Education through E-Learning

\section{Coefficients ${ }^{\mathrm{a}}$}

\begin{tabular}{|c|c|c|c|c|c|c|}
\hline \multirow[b]{2}{*}{ Model } & & \multicolumn{2}{|c|}{ Unstandardized Coefficients } & \multirow{2}{*}{$\begin{array}{l}\text { Standardized } \\
\text { Coefficients } \\
\text { Beta }\end{array}$} & \multirow[b]{2}{*}{$\mathrm{t}$} & \multirow[b]{2}{*}{ Sig. } \\
\hline & & B & Std. Error & & & \\
\hline 1 & (Constant) & 1.896 & .316 & & 5.993 & .000 \\
\hline & $\begin{array}{l}\text { Provision of Distance } \\
\text { Education through E- } \\
\text { Learning }\end{array}$ & .519 & .076 & .568 & 6.827 & .000 \\
\hline
\end{tabular}

a. Dependent Variable: Cost Savings made by Students

From the above output of regression analysis, the following regression equation has been created for hypothesis 1 .

$\boldsymbol{Y}=1.896+0.519 \boldsymbol{X}$

Where: $\mathbf{X}=$ Provision of Distance Education through E-Learning

$\mathbf{Y}=$ Cost Savings made by the Students

The above-highlighted regression equation clearly depicts that one unit increase under the provision of distance education through e-learning (i.e., explanatory variable) will (ceteris paribus) increase the cost savings made by the students (i.e., explained variable) by 0.519 . Similarly, upon analyzing the $t$-statistic value, it is evident that the explained variable is statistically significant at 0.05 level of significance. This is because the critical value of T-statistic is appropriately passing the rule of 2 (Seber\& Lee, 2012)since it is around 6.827, which is greater than 2. Moreover, the P-value of the explained variable is also below 0.05 , which further proves that this explained variable is statistically significant at a 95 percent confidence interval.

Likewise, upon analyzing the model summary table, it can be seen that the value of $\mathrm{R}$ is around 0.568 , which shows that the explained and explanatory variables under this model are correlated to each other by 56.8 percent. On the other hand, the value of $\mathrm{R}$ square is depicting that 32.2 percent change under the explained variable (i.e., Cost Savings made by Students) is accounted for by the change within the explained variable (i.e., provision of distance education through e-learning). Moreover, the adjusted $\mathrm{R}$ squared is also showing a similar trend (i.e., 31.5 percent) by highlighting the true impact on the explained variable.

On the other hand, upon examining the table of ANOVA, it can be seen that the value of the degree of freedom is 98. By using this value in order to determine the critical value of $\mathrm{F}$ statistic under the $\mathrm{F}$ distribution table at 0.05 level of significance (see appendix 2), a value of 3.936 will be obtained for one explained variable. The value of F-statistic under the table of ANOVA is around 46.607 which is greater than 3.936. This means that the entire regression model is adequately passing the f-test and it is statistically significant at a 95 percent confidence interval. Moreover, the value of significance under the table of ANOVA is also less than 0.05 which further proves that hypothesis 1 has been accepted by the above model and it is statistically significant.

\section{E-Learning and Cost Borne by Virtual Universities}

Table 6: Regression Analysis for Hypothesis 2

\section{Model Summary}

\begin{tabular}{|l|l|l|l|l|}
\hline Model & $\mathrm{R}$ & R Square & $\begin{array}{l}\text { Adjusted } \\
\text { Square }\end{array}$ & $\begin{array}{l}\text { Std. Error of } \\
\text { the Estimate }\end{array}$ \\
\hline 1 & $.907^{\mathrm{a}}$ & .822 & .820 & .26654 \\
\hline
\end{tabular}

a. Predictors: (Constant), Provision of Distance Education through

E-Learning

ANOVA ${ }^{\mathrm{a}}$

\begin{tabular}{|ll|l|l|l|l|l|}
\hline Model & & Sum of Squares & df & Mean Square & F & Sig. \\
\hline 1 & Regression & 32.125 & 1 & 32.125 & 452.188 & $.000^{\mathrm{b}}$ \\
& Residual & 6.962 & 98 & .071 & & \\
& Total & 39.088 & 99 & & & \\
\hline
\end{tabular}


a. Dependent Variable: Cost Savings made by Virtual Universities

b. Predictors: (Constant), Provision of Distance Education through E-Learning

Coefficients $^{\mathrm{a}}$

\begin{tabular}{|c|c|c|c|c|c|c|}
\hline \multirow[b]{2}{*}{ Model } & & \multicolumn{2}{|c|}{ Unstandardized Coefficients } & \multirow{2}{*}{\begin{tabular}{|l}
$\begin{array}{l}\text { Standardized } \\
\text { Coefficients }\end{array}$ \\
Beta \\
\end{tabular}} & \multirow[b]{2}{*}{$\mathrm{t}$} & \multirow[b]{2}{*}{ Sig. } \\
\hline & & B & Std. Error & & & \\
\hline 1 & (Constant) & -.404 & .215 & & -1.878 & .063 \\
\hline & $\begin{array}{l}\text { Provision of Distance } \\
\text { Education through } \\
\text { Learning }\end{array}$ & 1.099 & .052 & .907 & 21.265 & .000 \\
\hline
\end{tabular}

a. Dependent Variable: Cost Savings made by Virtual Universities

For hypothesis 2, the following regression equation has been created to depict the relationship between explained and explanatory variables under the model.

$\boldsymbol{Y}=1.099 \boldsymbol{X}-0.404$

Where: $\mathbf{X}=$ Provision of Distance Education through E-Learning

$\mathbf{Y}=$ Cost Savings made by Virtual Universities

It can be clearly seen from the above regression equation that 1 unit increase under the explanatory variable (i.e., Provision of Distance Education through E-Learning) will increase the value of the explained variable (i.e., Cost Savings made by Virtual Universities) by 1.099 when rest of the factors remain constant. Similarly, the explanatory variable under this model is also passing the t-test (based on the rule of 2) since the value of $t$ statistic is around 21.265, which is greater than 2 (Seber\& Lee, 2012). Likewise, the p-value of this variable is also below 0.05 level of significance which is further validating that the explanatory variable is statistically significant at a 95 percent confidence interval.

The R-value (i.e., the value of correlation) is indicating that the explained and explanatory variables under this model are correlated to each other by 90.7 percent. The value of R-square is depicting that around 82.2 percent change within the explained variable is accounted for by the change under the independent variable (i.e., Provision of Distance Education through E-Learning). Whereas, the adjusted R squared is also depicting the same trend (i.e., 82 percent). It is already known that at the value of 98 under the degree of freedom, the critical value within the F-distribution table at 0.05 level of significance will be 3.936. Again this value is less than the F-statistic value (i.e., 452.188) highlighted by the table of ANOVA, which proves that the entire regression model is statistically significant. Moreover, the value of significance that is depicted by the table of ANOVA is also less than 0.05 level. This further validates that hypothesis 2 has been accepted by the model at a 95 percent confidence interval.

\section{E-Learning and Improved Academic Performance}

Table 7: Regression Analysis for Hypothesis 3

Model Summary

\begin{tabular}{|c|c|c|c|c|}
\hline Model & $\mathrm{R}$ & R Square & $\begin{array}{c}\text { Adjusted R } \\
\text { Square }\end{array}$ & $\begin{array}{c}\text { Std. Error of } \\
\text { the Estimate }\end{array}$ \\
\hline 1 & $.886^{\mathrm{a}}$ & .785 & .782 & .31132 \\
\hline
\end{tabular}

a. Predictors: (Constant), Provision of Distance Education through

$$
\text { E-Learning }
$$

ANOVAa

\begin{tabular}{|ll|l|l|l|l|l|}
\hline Model & & Sum of Squares & $\mathrm{df}$ & Mean Square & $\mathrm{F}$ & Sig. \\
\hline 1 & Regression & 34.603 & 1 & 34.603 & 357.028 & $.000^{\mathrm{b}}$ \\
& Residual & 9.498 & 98 & .097 & & \\
& Total & 44.101 & 99 & & & \\
\hline
\end{tabular}

a. Dependent Variable: Improved Performance/Grades

b. Predictors: (Constant), Provision of Distance Education through E-Learning 


\section{Coefficients a}

\begin{tabular}{|c|c|c|c|c|c|c|}
\hline \multirow[b]{2}{*}{ Model } & & \multicolumn{2}{|c|}{ Unstandardized Coefficients } & \multirow{2}{*}{$\begin{array}{l}\text { Standardized } \\
\text { Coefficients } \\
\text { Beta } \\
\end{array}$} & \multirow[b]{2}{*}{$\mathrm{t}$} & \multirow[b]{2}{*}{ Sig. } \\
\hline & & $\mathrm{B}$ & Std. Error & & & \\
\hline 1 & (Constant) & -.548 & .251 & & -2.185 & .031 \\
\hline 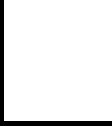 & $\begin{array}{llr}\text { Provision of } & \text { Distance } \\
\text { Education } & \text { through } \\
\text { Learning } & & \end{array}$ & 1.140 & .060 & .886 & 18.895 & .000 \\
\hline
\end{tabular}

a. Dependent Variable: Improved Performance/Grades

For the final hypothesis, the following regression equation has been created by utilizing the values provided by the table of coefficients.

$\boldsymbol{Y}=1.140 \mathrm{X}-0.548$

Where: $\mathbf{X}=$ Provision of Distance Education through E-Learning

$\mathbf{Y}=$ Improved Performance/Grades

It can be seen from the equation that when the provision of distance education through e-learning (i.e., explanatory variable) is increased by one unit, the academic performance of students (explained variable) is improved by 1.140 when rest of the factors are dormant. Similarly, the explanatory variable under the regression equation is also passing the t-test since the t-statistic value of the variable is around 18.895, which is greater than 2 (Seber\& Lee, 2012). Moreover, the p-value of this variable is also below the 0.05 level of significance, which further indicates that it is statistically significant.

From the model summary table, it is evident that the explained and explanatory variables under the regression equation are correlated to each other by 88.6 percent. Moreover, around 78.5 percent change (i.e., R-square value) in the dependent variable under the model is accounted for by the variation within the independent variable. The adjusted $\mathrm{R}$ squared is also providing the same trend (i.e., 78.2 percent).

In addition to this, the F-statistic value under the table of ANOVA (i.e., 357.028) is also above the critical value of 3.936 which was obtained at the degree of freedom of 98 within the f-distribution table at 0.05 level of significance. Moreover, the value of significance in the ANOVA table is also below the 0.05 level. These results clearly indicate that the entire model is statistically significant and hypothesis 3 has been accepted by the above model at a 95 percent confidence interval.

\section{CONCLUSION}

Upon concluding, it is evident that the provision of distance education through the platforms or technologies of e-learning has a high potential to reduce the expenditures for both the students and virtual universities. These findings are highly in line with the findings/inferences which were made by the previous authors related to the topic of e-learning that has been examined and discussed thoroughly under the literature review of this report.

Thus, from the students' perspective, it can be inferred that the platforms of e-learning allows those students who are living in remote areas (especially within rural regions) to save their costs/expenditures significantly that might be associated with traveling expenses, finding an appropriate accommodation to live near the educational institutes, buying hard copies of their course/learning materials, and so forth(Yusuf \& Al-Banawi, 2013). This is because by using such platforms, students are not compelled to go anywhere from their homes to gain education since they are able to attain it electronically from the online lectures, e-books, videos and other learning material that is provided by their teachers. Similarly, as the fees that are charged by virtual universities are relatively less than the fees that are charged by those universities which provide education under their physical premises, students are also able to save significant cost associated with obtaining the desired education related to their chosen field/domain on the platforms of elearning(Middleton, 2010).

On the other hand, from the perspective of virtual universities, it can also be inferred that the platforms of e-learning allow these universities to save their cost associated with building more infrastructures or facilities in remote areas to provide education to the students. These cost savings can also be in the form of reduced expenditures related to hiring additional staff, as well as resources to provide education to the students. This is because by using the platforms of e-learning, universities are able to 
provide education to the students by utilizing their existing resources or teachers even if these universities operate on their full capacities under their existing infrastructure (Sejzi \& Arisa, 2013).

The analyses also adequately depicted that the platforms of e-learning to provide distance education are also playing a significant role in enhancing the academic performance or grades of the students who might be attaining education on such platforms from remote areas. Again, several inferences can be made to support this finding. For instance, one logical explanation to justify this finding is that e-learning platforms offer flexibility to the students in managing their studies according to their own preferences(Romero \& Barbera, 2011).

\section{RECOMMENDATIONS}

1. The government should support these students by either providing them financial aid/assistance or distributing/providing the needed resources to them directly in order to help them attain education from the platforms of e-learning.

2. The government should allocate a certain portion of the budget in improving the infrastructure of the internet under remote areas, in order to eradicate the problem associated with connectivity issues that can become obstacles for the students to attain distance education by using e-learning technology.

3. Finally, it is also recommended to provide more training programs to both the teachers and students in order to help them learn the use of the software tools associated with e-learning technology so that they can effectively provide and attain education, respectively.

\section{REFERENCES}

Ahmed, M. U., Hussain, S., \& Farid, S. (2018). Factors Influencing the Adoption of e-Learning in an Open and Distance Learning Institution of Pakistan. Electronic Journal of e-Learning, 16(2), 148-158.

Akhtar, N., \& Tuba, N. (2015). Diffusing ICT to enhance students' academic writing skills: An experimental study at a business institute in Karachi, Pakistan. International Journal of English and Education, 4(3), 340-351.

Akhtar, N., \& Tuba, N. (2015) Using social networking sites (SNS) in students' learning experiences: An experimental study at higher secondary school Karachi, Pakistan. International Journal of English and Education, 4(3), 464-476.

Anderson, T., \&Dron, J. (2011). Three generations of distance education pedagogy. The International Review of Research in Open and Distributed Learning, 12(3), 80-97.

Aparicio, M., Bacao, F., \& Oliveira, T. (2016). An e-learning theoretical framework. An e-learning theoretical framework, (1), 292-307.

Arkorful, V., \&Abaidoo, N. (2015). The role of e-learning, advantages and disadvantages of its adoption in higher education. International Journal of Instructional Technology and Distance Learning, 12(1), 2942.

Assareh, A., \&Bidokht, M. H. (2011). Barriers to e-teaching and e-learning. Procedia Computer Science, 3, 791795.

Boling, E. C., Hough, M., Krinsky, H., Saleem, H., \& Stevens, M. (2012). Cutting the distance in distance education: Perspectives on what promotes positive, online learning experiences. The Internet and Higher Education, 15(2), 118-126.

Bonett, D. G., \& Wright, T. A. (2015). Cronbach's alpha reliability: Interval estimation, hypothesis testing, and sample size planning. Journal of Organizational Behavior, 36(1), 3-15.

Borstorff, P. C., \& Lowe, S. K. (2007). Student perceptions and opinions toward e-learning in the college environment. Academy of Educational Leadership Journal, 11(2).

Cakmak, E., \&Yilmaz, S. M. (2014). E-learning from the perspective of right to education. Procedia-Social and Behavioral Sciences, 116, 426-430.

Chang, V. (2016). Review and discussion: E-learning for academia and industry. International Journal of Information Management, 36(3), 476-485.

Chapman, B. F., \& Henderson, R. G. (2010). E-learning quality assurance: A perspective of business teacher educators and distance learning coordinators. Delta Pi Epsilon Journal, 52(1). 
Chetwynd, F., \& Dobbyn, C. (2011). Assessment, feedback and marking guides in distance education. Open Learning: The Journal of Open, Distance and e-Learning, 26(1), 67-78.

Cook, D. A., \&Triola, M. M. (2014). What is the role of e-learning? Looking past the hype. Medical education, 48(9), 930-937.

Cohen, P., West, S. G., \& Aiken, L. S. (2014). Applied multiple regression/correlation analysis for the behavioral sciences. Psychology Press.

Croasmun, J. T., \&Ostrom, L. (2011). Using Likert-Type Scales in the Social Sciences. Journal of Adult Education, 40(1), 19-22.

Dawley, L., \&Dede, C. (2014). Situated learning in virtual worlds and immersive simulations. In Handbook of research on educational communications and technology (pp. 723-734). Springer, New York, NY.

Etikan, I., Musa, S. A., \&Alkassim, R. S. (2016). Comparison of convenience sampling and purposive sampling. American journal of theoretical and applied statistics, 5(1), 1-4.

Farid, S., Ahmad, R., Niaz, I. A., Arif, M., Shamshirband, S., \&Khattak, M. D. (2015). Identification and prioritization of critical issues for the promotion of e-learning in Pakistan. Computers in Human Behavior, 51, 161-171.

Gauvreau, S. A., Hurst, D., Cleveland-Innes, M., \&Hawranik, P. (2016). Online professional skills workshops: Perspectives from distance education graduate students. The International Review of Research in Open and Distributed Learning, 17(5).

Government of Pakistan. (2017). National Education Policy - 2017. Islamabad: Ministry of Federal Education and Professional Training Government of Pakistan. Retrieved from http://www.moent.gov.pk/userfiles1/file/National\%20Educaiton\%20Policy\%202017.pdf

Gunawardena, C. N., \&McIsaac, M. S. (2013). Distance education. In Handbook of research on educational communications and technology (pp. 361-401). Routledge.

Harsasi, M., \&Sutawijaya, A. (2018). Determinants of student satisfaction in online tutorial: A study of a distance education institution. Turkish Online Journal of Distance Education, 19(1), 89-99.

Iqbal, M. J., \& Ahmad, M. (2010). Enhancing quality of education through e-learning: the case study of AllamaIqbal Open University. Turkish Online Journal of Distance Education, 11(1), 84-97.

Jung, I., Wong, T. M., \&Belawati, T. (Eds.). (2013). Quality assurance in distance education and e-learning: Challenges and solutions from Asia. SAGE Publications India.

Kanwal, F., \&Rehman, M. (2017). Factors affecting e-learning adoption in developing countries-empirical evidence from Pakistan's higher education sector. IEEE Access, 5, 10968-10978.

Kibelloh, M., \&Bao, Y. (2014). Perceptions of international female students toward e-learning in resolving high education and family role strain. Journal of educational computing research, 50(4), 467-487.

Kimiloglu, H., Ozturan, M., \&Kutlu, B. (2017). Perceptions about and attitude toward the usage of e-learning in corporate training. Computers in Human Behavior, 72, 339-349.

King, E., \&Boyatt, R. (2015). Exploring factors that influence adoption of e-learning within higher education. British Journal of Educational Technology, 46(6), 1272-1280.

Korthagen, F. A. (2010). Situated learning theory and the pedagogy of teacher education: Towards an integrative view of teacher behavior and teacher learning. Teaching and teacher education, 26(1), 98106.

Kundi, G. M., \& Nawaz, A. (2014). From e-Learning 1.0 to e-Learning 2.0: threats \& opportunities for higher education institutions in the developing countries. European Journal of Sustainable Development, 3(1), 145-160.

Latchem, C., \& Jung, I. (2012). Quality assurance and accreditation in distance education and e-Learning: Models, policies and research. Routledge.

Macleod, J., \&Kefallonitis, E. (2017). Trends affecting e-learning experience management. In Strategic Innovative Marketing (pp. 753-758). Springer, Cham.

Maqsood, F. (2018, April 27). Govt allocates adequate funds for Prime Minister's Youth Programme. Retrieved from Business Recorder: https://www.brecorder.com/2018/04/27/414677/govt-allocatesadequate-funds-for-prime-ministers-youth-programme/

Mayer, R. E. (2017). Using multimedia for e-learning. Journal of Computer Assisted Learning, 33(5), 403-423.

Middleton, D. (2010). Putting the Learning into e-learning. European Political Science, 9(1), 5-12.

Miller, G., Benke, M., Chaloux, B., Ragan, L. C., Schroeder, R., Smutz, W., \& Swan, K. (2013). Leading the elearning transformation of higher education: Meeting the challenges of technology and distance education. Stylus Publishing, LLC.. 
Moore, M. G., \&Kearsley, G. (2011). Distance education: A systems view of online learning. Cengage Learning.

Nawaz, A. (2013). Using e-learning as a tool for education for all in developing states. International Journal of Science and Technology Education Research, 4(3), 38-46.

Nawaz, A., \&Kundi, G. M. (2010). Demographic implications for the user-perceptions of E-learning in higher education institutions of N-WFP, Pakistan. The Electronic Journal of Information Systems in Developing Countries, 41(1), 1-17.

Nawaz, A., \&Kundi, G. M. (2010). Predictor of e-learning development and use practices in higher education institutions (HEIs) of NWFP, Pakistan. Journal of Science and Technology Education Research, 1(3), 44-54.

Njenga, J. K., \&Fourie, L. C. H. (2010). The myths about e-learning in higher education. British journal of educational technology, 41(2), 199-212.

Ozcan, D., \&Genc, Z. (2016). Pedagogical Formation Education via Distance Education. Eurasia Journal of Mathematics, Science \& Technology Education, 12(2).

Peters, 0. (2013). Learning and teaching in distance education: Analyses and interpretations from an international perspective. Routledge.

Poulin, R., \&Straut, T. T. (2017). Distance Education Price and Cost Report. WICHE Cooperative for Educational Technologies (WCET).

Qureshi, I. A., Ilyas, K., Yasmin, R., \&Whitty, M. (2012). Challenges of implementing e-learning in a Pakistani university. Knowledge Management \& E-Learning, 4(3), 310.

Qureshi, I. A., Raza, H., \&Whitty, M. (2014). Facebook as e-learning tool for higher education institutes. Knowledge Management \& E-Learning, 6(4), 440.

Rahim Sajid, A. (2013). ICTs in learning: Problems faced by Pakistan. Journal of Research \& Reflections in Education (JRRE), 7(1).

Romero, M., \&Barbera, E. (2011). Quality of e-learners' time and learning performance beyond quantitative time-on-task. The International Review of Research in Open and Distributed Learning, 12(5), 125-137.

Rovai, A. P., \& Downey, J. R. (2010). Why some distance education programs fail while others succeed in a global environment. The Internet and Higher Education, 13(3), 141-147.

Seber, G. A., \& Lee, A. J. (2012). Linear regression analysis (Vol. 329). John Wiley \& Sons.

Sejzi, A. A., \&Arisa, B. (2013). Learning Management System (LMS) and Learning Content Management System (LCMS) at Virtual University. In 2nd International Seminar on Quality and Affordable Education (ISQAE), Johor, Malaysia. http://www. isqae. com.

Shah, G. U. D., Bhatti, M. N., Iftikhar, M., Qureshi, M. I., \&Zaman, K. (2013). Implementation of technology acceptance model in e-learning environment in rural and urban areas of Pakistan. World Applied Sciences Journal, 27(11), 1495-1507.

Tavakol, M., \&Dennick, R. (2011). Making sense of Cronbach's alpha. International journal of medical education, 2, 53.

Totaro, M. W., Tanner, J. R., Noser, T., Fitzgerald, J. F., \& Birch, R. (2005). Faculty perceptions of distance education courses: A survey. Journal of College Teaching \& Learning (TLC), 2(7).

Truong, H. M. (2016). Integrating learning styles and adaptive e-learning system: Current developments, problems and opportunities. Computers in human behavior, 55, 1185-1193. 